\title{
PENGARUH LATIHAN FISIK SELAMA HEMODIALISIS TERHADAP KEKUATAN OTOT PASIEN GAGAL GINJAL KRONIK DI RUANGAN HEMODIALISA RUMAH SAKIT AWAL BROS PANAM TAHUN 2017
}

\author{
(The Effect of Physical Exercises during Hemodialysis towards Strength \\ Patients with Chronic Kidney Failure on Hemodialysis Room at \\ Awal Bros Panam Hospital in 2017)
}

\author{
Elvi Murniarsih ${ }^{*}$ \\ *) Dosen Program Studi Ilmu Keperawatan Stikes Awal Bros Batam
}

\begin{abstract}
Patients who have chronic renal failure, one of the therapies that can be done to prolong his life is hemodialysis. A phenomenon found in the room of hemodialysis at Awal Bros Panam hospital, most of the patients undergoing hemodialysis experienced muscle weakness, muscle atrophy, and pain in standing after hemodialysis. This study was aimed to determine the effect of physical exercises during hemodialysis towards strength patients with chronic kidney failure on hemodialysis room at Awal Bros Panam hospital. Moreover, this research employed Quasi-Experiment method with time series design. The sample of this study was patients who underwenthemodialysis included in the inclusion criteria of 45 people. Physical exercise was done with time 45 minutes, 2 times a week according to hemodialysis schedule for 4 weeks or 8 times physical exercise. Expanding Dynamometer and Back Leg Dynamometer were used as the measuring instruments. The analysis that used was univariate analysis to figure out frequency and bivariate with Paired sample $t$-test and Wilxocon. The results showed there was an effect of physical exercise on hand muscle strength of $2.76 \mathrm{~kg}$ and an effect of physical exercise on leg muscle strength of $13.5 \mathrm{~kg}$. Also, The results of statistical tests showed the effect of physical exercise on hand and foot muscle strength in hemodialysis patients with p-value $0.001<\alpha(0.05)$. In other words, these results indicated that physical exercise can improve muscle strength of patients undergoing hemodialysis. Regarding the research findings, Educationalinstitutions and services need to hold discussions in the development of nursing actions during hemodialysis because physical exercise during hemodialysis is still a novelty.
\end{abstract}

Keywords: hemodialysis, physical exercises, muscle strength

\section{PENDAHULUAN}

Penyakit ginjal kronik atau chornic kidney disease adalah kemunduran fungsi ginjal yang berisfat progresif dan irreversibel dimana terjadi kegagalan kemampuan tubuh untuk mempertahankan keseimbangan metabolik, cairan dan elektrolit yang mengakibatkan uremia atau azotemia (Saferi, 2013). Penyakit ginjal ini terbagi menjadi dua yaitu penyakit ginjal kronik dan penyakit ginjal akut. Penyakit ginjal baik yang bersifat kronis maupun akut merupakan salah satu jenis penyakit yang serius dibuktikan dengan banyaknya kasus kematian pada manusia dengan latar belakang penyakit ginjal (Paul, 2015).
Penderita gagal ginjal kronik di seluruh dunia setiap tahunnya meningkat, pada tahun 2010 sekitar dua juta jiwa (Firmansyah, 2010). Menurut data WHO tahun 2011 Indonesia berada pada urutan ke-4 sebagai Negara penderita gagal ginjal terbanyak didunia dengan jumlah penderita mencapai 16 juta jiwa dan penderita penyakit ginjal kronik berkisar 100-150 per 1 juta penduduk dengan prevalensi mencapai 200-250 kasus per juta penduduk (Firmansyah, 2010). Berdasarkan PT Askes pada tahun 2010 pasien gagal ginjal berjumlah 17.505 orang, angka ini mengalami peningkatan 
sekitar lima ribu lebih pada tahun 2011 dengan jumlah 23.261 pasien, Jumlah pasien hemodialisis setiap tahunnya bertambah hal ini dibuktikan juga dari peningkatan jumlah pasien dengan penyakit ginjal kronik di rumah sakit Awal Bros Panam pada tahun2014 berjumlah 754 pasien, tahun 2015 berjumlah 1.337 pasien, tahun 2016 berjumlah 3.675 pasien dan tahun 2017 mulai dari bulan januari sampai sekarang berjumlah 1.484 pasien.

Terapi pergantian ginjal merupakan salah satu terapi yang dapat di lakukan pada pasien penyakit ginjal kronik. Terapi pergantian ginjal dapat berupa dialisis dan transplatansi ginjal (Ariani, 2016). Tindakan dialisis yang dimaksud adalah hemodialisis, hemodialisis merupakan suatu tindakan yang digunakan pada klien gagal ginjal untuk membuang zat-zat sisa metabolisme, zat toksik lainnya melalui membran semi permeabel sebagai pemisah antara darah dan cairan diaksat yang sengaja dibuat dalam dializer (Saferi, 2013).

Salah satu permasalahan yang sering dikeluhkan pasien yang menjalani hemodialisis rutin adalah kelemahan otot, kelemahan otot tersebut disebabkan adanya pengurangan aktivitas, atrofiotot, miopati otot, dan neuropati (Muniralanam, dalam sulistya ningsih, 2011). Kelemahan otot yang terjadi pada pasien hemodialysis seperti yang diterangkan dalam teori di atas di buktikan dari kelemahan otot yang terjadi pada pasien hemodialisis di rumah sakit awal bros panam, banyak diantara pasien yang mengalami kelemahan otot, hal ini nampak dari sikap pasien yang selalu bergantung kepada orang lain dalam aktifitas dirinya. Salah satu cara yang dapat dilakukan adalah dengan latihan fisik (Sulistyaningsih, 2011).
Latihan fisik merupakan sebagai pergerakan terencana, terstruktur yang dilakukan untuk memperbaiki atau memelihara satu atau lebih aspek kebugaran fisik (Orti, 2010). Latihan fisik dilakukan pada saat pasien menjalani hemodialisis. Latihan dapat dilakukan 30 menit sampai 45 menit dan secara umum diberikan sebelum hemodialysis selesai dilakukan (Cheema, dalam sulistyaningsih 2011). Latihan fisik yang dilakukan pada pasien yang menjalani hemodialysis dapat meningkatkan kekuatan otot.

Kekuatan otot adalah kemampuan otot atau sekelompok otot untuk melakukan satu kali kontraksi secara maksimal melawan tahanan atau beban (Widiastuti 2011). Kekuatan otot sebagai daya penggerak setiap aktifitas fisik merupakan dasar untuk memiliki kemampuan fisik lainnya, kekuatan otot dapat diukur dengan mengunakan dynamometer. Dynamometer merupakan alat untuk mengukur kekuatan otot yang valid dan reliable, hasil pengukurannya dinyatakan dalam $\mathrm{kg}$ (Widiastuti 2011).

Menurut hasil penelitian Dwi retno sulistyaningsih pada tahun 2014 tentang "Efektifitas latihan fisik selama hemodialysis terhadap peningkatan kekuatan otot pasien penyakit ginjal kronik di rumah sakit umum daerah Semarang" terdapat perbedaan yang signifikan kekuatan otot baik kekuatan otot kaki dan kekuatan otot tangan sebelum dan setelah dilakukan latihan fisik selama hemodialysis pada kelompok perlakuan dan kelompok control dengan nilai $\mathrm{p}=0.027$ dan $\mathrm{p}=0.030$, jadi latihan fisik selama hemodialysis terbukti efektif untuk meningkatkan kekuatan otot pada pasien penyakit ginjal kronik yang menjalani hemodialisis. 


\section{METODE}

Penelitian ini menggunakan desain penelitian quasy eksperiment dengan rancangan time series design yaitu pengukuran dilakukan secara berulangulang baik sebelum atau setelah diberikan manipulasi. Penelitian dilakukan di Ruangan hemodialisa Rumah Sakit Awal Bros Panam dengan jumlah sampel sebanyak 45 responden. Pengambilan sampel menggunakan purposive sampling sesuai dengan kriteria inklusi, yaitu bersedia menjadi responden dan menandatangani inform consent penelitian, pasien yang menjalani hemodialisis rutin, Pasien yang mengalami penyakit neourologis seperti lemah anggota gerak, pasien yang tidak mengalami sakit kepala hebat, mual muntah hebat dan pusing.

Kekuatan otot tangan dan kaki yang digunakan merupakan hasil pengukuran kekuatan otot sebelum dan sesudah diberikan latihan fisik selama 2 hari. Pengukuran kekuatan otot menggunakan alat Expanding dynamometer yang digunakan untuk mengukur kekuatan otot tangan dan Back leg dynamometer yang digunakan untuk mengukur kekuatan otot kaki. Nilai pre test nya diambil dari pengukuran pre test hari ke-1, dan nilai post test nya diambil dari nilai post test kekuatan otot pada hai ke-2. Analisa data yang digunakan yaitu analisa univariat menggunakan frekuensi dan analisa bivariat menggunakan uji Paired Samples T Test dan uji Wilcoxon untuk melihat pengaruh dari pemberian latihan fisik terhadap kekutan otot tangan dan kaki pada pasien yang menjalani hemodialisis.
HASIL

Tabel 2

Distribusi Karakteristik Responden

\begin{tabular}{lcc}
\multicolumn{2}{c}{$(\mathrm{n}=45)$} & \\
\multicolumn{1}{c}{ Karakteristik } & n & \% \\
\hline Usia: & & \\
Remaja Akhir 17-25 & 1 & 2.2 \\
Dewasa Awal 26-35 & - & - \\
Dewasa Akhir 36-45 & 6 & 13.3 \\
Lansia Awal 46-55 & 21 & 46.7 \\
Lansia Akhir 56-65 & 16 & 35.6 \\
Manula >65 & 1 & 2.2 \\
\hline Jenis Kelamin: & & \\
Laki-laki & 10 & 22.2 \\
Perempuan & 35 & 77.8 \\
\hline Pendidikan: & & \\
SD & 6 & 13.3 \\
SMP & 9 & 20.0 \\
SMA & 21 & 46.7 \\
PT & 9 & 20.0 \\
\hline Status Pekerjaan: & & \\
Bekerja & 16 & 35.6 \\
Tidak Bekerja & 29 & 64.4 \\
\hline Total & 15 & 100,0 \\
\hline
\end{tabular}

Tabel 2 di atas menunjukkan bahwa sebagian besar responden yang menjalani hemodialisa dalam penelitian ini berada pada rentang usia 46-55 tahun atau dapat dikategorikan lansia awal sebanyak $46,7 \%$ (21 orang) dan mayoritas berjenis kelamin perempuan yaitu sebanyak $77.8 \%$ (35 orang). Terkait status pendidikan mayoritas responden merupakan tamatan SMA yaitu sebanyak 46,7\% (21 orang). Pada kategori status pekerjaan sebagian besar responden tidak bekerja sebanyak $64,4 \%$ (29 orang). 
Grafik 1

Rata-Rata Kekuatan Otot Tangan dan

Kekuatan Otot Kaki Sebelum dan

Sesudah Diberikan Latihan Fisik Pada

Pasien yang menjalani Hemodialisis

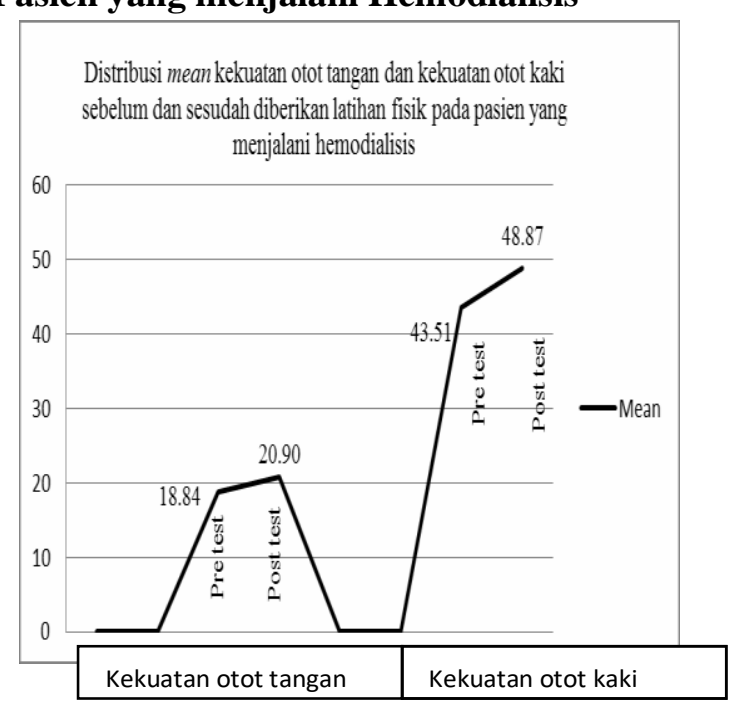

Grafik diatas menunjukkan rata-rata kekuatan otot tangan sebelum dan sesudah intervensi adalah 18.84 dan 20.90 . Sedangkan rata-rata kekuatan otot kaki sebelum dan sesudah intervensi adalah 43.51 dan 48.87 .

\section{Tabel 4}

Distribusi kekuatan otot tangan sebelum dan sesudah diberikan latihan fisik pada pasien yang menjalani hemodialisis

\begin{tabular}{clcr}
\hline Variabel & $\begin{array}{l}\text { Kategori } \\
\text { Kekuatan } \\
\text { otot }\end{array}$ & n & \% \\
Pre test & Baik & 0 & $0 \%$ \\
& Sedang & 1 & $31.1 \%$ \\
& Kurang & 4 & $68.9 \%$ \\
& & 3 & \\
Post test & Baik & 1 & \\
& Sedang & 3 & $0 \%$ \\
& Kurang & 5 & $8 \%$ \\
& & 1 & 22. \\
& & 0 & $2 \%$ \\
\hline
\end{tabular}

Tabel 4 menunjukkan frekuensi responden yang memiliki kekutan otot tangan dengan kategori sedang sebelum diberikan latihan fisik adalah $31.1 \%$ (14 orang) dan yang memiliki kekuatan otot tangan dengan kategori kurang adalah sebanyak $68.9 \%$ (31 orang) serta tidak ada responden yang memiliki kekuatan otot tangan dengan kategori baik.

Selanjutnya frekuensi responden yang memiliki kekuatan otot tangan dengan kategori sedang setelah diberikan latihan fisik adalah $77.8 \%$ (35 orang) dan yang memiliki kekuatan otot tangan dengan kategori kurang adalah sebanyak $22.2 \%$ ( 10 orang) serta tidak ada responden yang memiliki kekuatan otot tangan dengan kategori baik.

Tabel 5

Distribusi kekuatan otot kaki sebelum dan sesudah diberikan latihan fisik pada pasien yang menjalani hemodialisis

\begin{tabular}{cclc}
\hline Variabel & $\begin{array}{c}\text { Kategori } \\
\text { Kekuatan } \\
\text { otot }\end{array}$ & n & \% \\
Pre & Baik & 0 & $0 \%$ \\
test & Sedang & 2 & $4.4 \%$ \\
& Kurang & 43 & $95.6 \%$ \\
Post & Baik & 0 & $0 \%$ \\
test & Sedang & 6 & $13.3 \%$ \\
& Kurang & 39 & $86.7 \%$ \\
\hline
\end{tabular}

Tabel 5 menunjukkan frekuensi responden yang memiliki kekutan otot kaki dengan kategori sedang sebelum diberikan latihan fisik adalah $4.4 \%$ (2 orang) dan yang memiliki kekuatan otot kaki dengan kategori kurang adalah sebanyak $95.6 \%$ (43 orang) serta tidak ada responden yang memiliki kekuatan otot kaki dengan kategori baik.

Selanjutnya frekuensi responden yang memiliki kekuatan otot kaki dengan kategori sedang setelah diberikan latihan fisik adalah $13.3 \%$ (6 orang) dan yang memiliki kekuatan otot kaki dengan kategori kurang 
adalah sebanyak $86.7 \%$ (39 orang) serta tidak ada responden yang memiliki kekuatan otot kaki dengan kategori baik.

Analisa data yang digunakan untuk membandingkan hasil pengukuran kekuatan otot tangan sebelum dan sesudah diberikan latihan fisik menggunakan Wilcoxon. Sedangkan untuk membandingkan hasil pengukuran kekuatan otot kaki sebelum dan sesudah diberikan latihan fisik menggunakan uji Paired Samples $T$ Test. Pengolahan data dengan menggunakan metode statistik didapatkan hasil sebagai berikut:

Tabel 6

Perbedaan Rata-Rata Kekuatan Otot

Tangan Sebelum dan Sesudah

Diberikan Latihan Fisik Pada Pasien

Hemodialisis

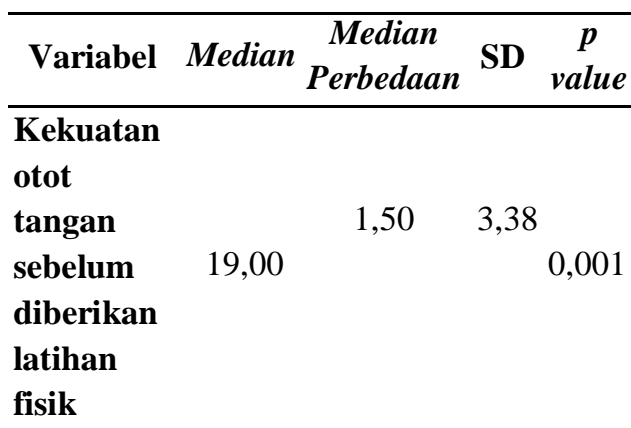

\section{Kekuatan}

otot tangan

sesudah

diberikan

20,50

latihan

fisik

Tabel 6 menunjukkan bahwa hasil

uji statistik menggunakan Wilcoxon didapatkan median kekuatan otot tangan sebelum diberikan latihan fisik adalah 19,00 sedangkan median kekuatan otot tangan sesudah diberikan latihan fisik yaitu 20,50. Hasil uji statistik pada median kekuatan otot tangan sebelum dan sesudah diberikan latihan fisik diperolah nilai $p$ value $0,001<\alpha(0,05)$. Hal ini menunjukkan bahwa ada pengaruh pemberian latihan fisik terhadap kekuatan otot tangan pada pasien hemodialisa.

Tabel 7

Perbedaan Rata-Rata Kekuatan Otot Kaki Sebelum dan Sesudah Diberikan Latihan Fisik Pada Pasien Hemodialisis

\begin{tabular}{cccc}
\hline Variabel & Mean $\begin{array}{c}\text { Mean } \\
\text { Perbedaan }\end{array}$ & SD & $\begin{array}{c}p \\
\text { value }\end{array}$ \\
\hline
\end{tabular}

Kekuatan

otot kaki

$\begin{array}{lllll}\text { sebelum } & 39.98 & 13,5 & 11,69 & 0,001\end{array}$

diberikan

latihan fisik

Kekuatan

otot kaki $\quad 10,64$

sesudah $\quad 53.48$

diberikan

latihan fisik

Tabel 7 menunjukkan bahwa hasil uji statistik menggunakan Paired Samples TTest didapatkan mean kekuatan otot kaki sebelum dan sesudah diberikan latihan fisik adalah 53.48. Hasil uji statistik pada mean kekuatan otot kaki sebelum dan sesudah diberikan latihan fisik diperolah nilai $\mathrm{p}$ value $0,001<\alpha(0,05)$. Hal ini menunjukkan bahwa ada pengaruh pemberian latihan fisik terhadap kekuatan otot kaki pada pasien hemodialisa.

\section{PEMBAHASAN}

1. Karakteristik responden yang menjalani hemodialysis

Hasil penelitian yang telah dilakukan pada responden yang menjalani hemodialisis di ruangan hemodialisis Rumah Sakit Awal Bros Panam didapatkan bahwa sebagian besar responden berdasarkan usia berada pada kategori lansia awal (46-55 tahun) sebanyak $46,7 \%$. Hal ini sejalan 
dengan penelitian Dani (2015) didapatkan hasil bahwa mayoritas responden yang menjalani hemodialisis berada pada rentang usia 45-60 tahun yaitu $69,4 \%$.

Menurut peneliti, dalam penelitian ini umur bukanlah sebagai patokan faktor yang mencetus terjadinya gagal ginjal kronik. Pada dasarnya dari beberapa literature dinyatakan bahwa penyebab terjadinya gagal ginjal kronik adalah, akibat penyakit dari ginjal sendiri maupun sebagai komplikasi dari penyakit diluar ginjal seperti penyakit sistemik (diabetes mellitus, hipertensi dan kolesterol tinggi), Syndroma Lupus Erythematosus (SLE), preeklamsi, obatobatan dan kehilangan banyak cairan yang mendadak pada pasien luka bakar (Muttaqin \& Sari, 2011).

Mayoritas jenis kelamin responden dalam penelitian ini adalah perempuan yaitu sebanyak 35 orang (77.8\%). Hal ini sejalan dengan penelitian Anastasya (2015) yang menyatakan mayoritas responden yang menjalani Hemodialisis dalam penelitiannya adalah perempuan yaitu sebanyak 56,7 \%. Berbeda dengan penelitian yang dilakukan oleh Musa, Kundre, dan Babakal (2014) menyatakan responden laki-laki lebih banyak mengalami gagal ginjal kronik karena secara keseluruhan insiden gagal ginjal kronik lebih sering dialami oleh laki-laki. Pada dasarnya setiap penyakit dapat menyerang manusia baik laki-laki maupun perempuan, tetapi ada beberapa penyakit terdapat perbedaan frekuensi antara laki-laki dan perempuan. Tidak ada literatur yang menyatakan bahwa jenis kelamin merupakan patokan untuk menyebabkan seseorang mengalami gagal ginjal kronik (Nurchayati, 2012).

Sebagian besar pendidikan responden dalam penelitian ini adalah SMA yaitu sebesar 46,7\%. Hal ini sejalan dengan penelitian Oxtavia (2013) yang menyatakan tingkat pendidikan pasien gagal ginjal kronik mayoritas adalah SMA sebanyak 32 orang $(53,3 \%)$. Tingkat pendidikan seseorang mempengaruhi kemampuan seseorang dalam menerima informasi dan mengolahnya sebelum menjadi perilaku yang baik maupun buruk sehingga berdampak terhadap status kesehatannya (Notoatmodjo, 2010). Responden yang memiliki pendidikan tinggi akan memiliki pengetahuan yang luas. Hal ini akan memungkinkan responden untuk dapat mengontrol dirinya dalam mengatasi masalah yang dihadapi, mempunyai rasa percaya diri yang tinggi, berpengalaman, dan mempunyai perkiraan yang tepat untuk mengatasi kejadian, mudah mengerti tentang apa yang diajarkan petugas kesehatan (Kusumawardani, 2010). Dalam penelitian ini, peneliti berasumsi bahwa semakin tinggi pendidikan makan akan semakin mudah untuk memberi penjelasan tentang penyakit individu.

Mayoritas responden dalam peneliitian ini adalah tidak bekerja sebanyak 29 orang (64.4\%), dimana pasien mengatakan berhenti bekerja sejak menjalani hemodialisis secara rutin 2 kali seminggu. Pasien juga mengatakan bahwa waktunya banyak habis oleh karena harus bolak-balik untuk menjalani terapi hemodialisis, apalagi banyak pasien yang datang dari luar daerah sehingga beberapa pasien 
terpaksa berhenti bekerja ataupun pensiun dini.

$$
\text { Sejalan dengan penelitian }
$$
Nurchayati (2011) bahwa ditemukan sebagian responden tidak bekerja yaitu sebanyak 56 orang $(58,9 \%)$. Menurut penelitiannya pada umumnya pasien yang tidak bekerja menyatakan bahwa mereka sudah tidak kuat lagi dan sering merasa cepat kelelahan.

2. Pengaruh Latihan Fisik Terhadap Kekuatan Otot Tangan dan Otot Kaki Pada Responden yang Menjalani Hemodialisis

Penelitian ini dilakukan pada 45 responden. Setiap responden diberikan latihan fisik selama 2 kali seminggu sesuai jadwal hemodialisis masingmasing selama 4 minggu. Pre test kekuatan otot tangan dan otot kaki diukur 1 minggu sebelum diberikan latihan fisik dan post test nya di lakukan 1 minggu setelah latihan diberikan latihan fisik.

Dalam penelitian ini kekuatan otot tangan dan kaki responden dikategorikan menjadi 3 kategori yaitu baik, sedang, dan kurang. Untuk kekuatan otot tangan dikategorikan baik jika nilainya $>30 \mathrm{~kg}$, sedang jika 20-30 $\mathrm{kg}$ dan kurang jika <20 kg. Sedangkan untuk kekuatan otot kaki dikategorikan baik jika >114 kg, sedang jika 66-113 $\mathrm{kg}$ dan kurang jika $<65 \mathrm{~kg}$.

Berdasarkan hasil pengukuran terhadap kekuatan otot tangan responden didapatkan hasil frekuensi responden yang memiliki kekuatan otot tangan sebelum diberikan latihan fisik dengan kategori sedang adalah $31.1 \%$ (14 orang), kategori kurang 68.9\% (31 orang), dan tidak ada kekuatan otot responden yang dikategorikan baik.
Sedangkan untuk kategori kekuatan otot tangan sesudah diberikan latihan fisik diperoleh hasil kategori sedang $77.8 \%$ (35 orang), kurang $22.2 \%$ (10 orang), serta tidak ada kekuatan otot responden yang dikategorikan baik.

Selanjutnya untuk hasil pengukuran terhadap kekuatan otot kaki responden didapatkan hasil frekuensi responden yang memiliki kekuatan otot kaki sebelum diberikan latihan fisik dengan kategori sedang adalah $4.4 \%$ (2 orang), kategori kurang 95.6\% (43 orang), dan tidak ada kekuatan otot responden yang dikategorikan baik.

Sedangkan untuk kategori kekuatan otot kaki sesudah diberikan latihan fisik diperoleh hasil kategori sedang $13.3 \%$ (6 orang), kurang $86.7 \%$ (39 orang), serta tidak ada kekuatan otot responden yang dikategorikan baik.

Pengukuran median kekuatan otot tangan sebelum dan sesudah diberikan latihan fisik adalah 19,00 $\mathrm{kg}$ dan 20.5 kg. Karena sebaran data pada variable ini tidak normal $p$ value 0,089 dan $0,014, \mathrm{p}$ value $<\alpha(0,05)$ maka peneliti menggunakan uji Wilcoxon untuk melihat pengaruh dari pemberian latihan fisik terhadap kekuatan otot tangan.

Hasil uji Wilcoxon terhadap kekuatan otot tangan menunjukkan $\mathrm{p}$ value 0,001 berarti nilai $p$ value $<\alpha$ $(0,05)$, artinya $\mathrm{H}_{0}$ ditolak. Dapat disimpulkan bahwa ada pengaruh yang signifikan pemberian latihan fisik terhadap kekuatan otot tangan pada responden yang menjalani hemodialisis. Selanjutnya peneliti akan memaparkan mean kekuatan otot kaki sebelum dan sesudah diberikan latihan fisik yaitu $39.98 \mathrm{~kg}$ dan $53,48 \mathrm{~kg}$. Sebaran data pada variable ini normal 
yaitu $p$ value 0,091 dan 0,414 , $\mathrm{p}$ value

$>\alpha(0,05)$. Maka untuk melihat pengaruh pemberian latihan fisik terhadap kekuatan otot kaki peneliti menggunakan uji Paired Sample $T$ Test.

Berdasarkan hasil dari uji Paired Sample T Test pada kekuatan otot kaki sebelum dan sesudah diberikan latihan fisik diperoleh nilai $p$ value $0,001, p$ value $<\alpha(0,05)$. Hal ini berarti ada pengaruh yang signifikan terhadap kekuatan otot kaki sebelum dan sesudah diberikan latihan fisik.

Penelitian yang dilakukan Sulistyaningsih (2010) dengan judul "Efektifitas latihan fisik selama hemodialisis terhadap peningkatan kekuatan otot pasien penyakit ginjal kronik di Rumah Sakit Umum Daerah Kota Semarang" didapatkan hasil bahwa latihan fisik terbukti efektif untuk meningkatkan kekuatan otot pada pasien penyakit ginjal kronik yang menjalani hemodialisis dengan $p$ value 0,001 .

Latihan fisik selama hemodialisis dapat meningkatkan aliran darah pada otot, memperbesar jumlah kapiler serta memperbesar luas dan permukaan kapiler sehingga meningkatkan perpindahan urea dan toksin dari jaringan ke vaskuler yang kemudian dialirkan ke dialyzer atau mesin hemodialisis (Parson et al, 2017). Latihan fisik yang dilakukan selama hemodialisis dapat meningkatkan dyalisis efficacy yaitu mengurangi efek racun dari uemik syndrome yang dapat mengakibatkan komplikasi pada pasien penyakit ginjal kronik. Pasien yang melakukan latihan fisik selama hemodialisis memungkinkan untuk lebih sedikit mengalami komplikasi.
Aliran darah melalui jaringan meningkat saat dilakukan latihan fisik menggunakan otot-otot tungkai bawah memungkinkan kapiler untuk membuka lebih banyak sehingga memberikan luas permukaan yang lebih besar untuk pertukaran zat dari jaringan ke darah.

Latihan fisik selama hemodialisis belum banyak diterapkan di unit hemodialisis di Indonesia meskipun manfaat latihan fisik sangat besar akan tetapi pasien dialysis ternyata sangat tidak aktif atau pemalas (Nasution, 2010). Salah satu factor yang menyebabkan mereka tidak aktif adalah rasa mengantuk saat dilakukan hemodialisis. Berdasarkan wawancara yang dilakukan pada pasien yang menjalani hemodialisis kurang lebih $90 \%$ mengatakan malam hari menjelang hemodialisis mayoritas diantara mereka tidak tidur sehingga saat dilakukan hemodialisis merupakan kesempatan untuk mengganti tidur yang tertunda.

Kurangnya perhatian terhadap latihan fisik ini banyak factor yang mempengaruhinya. Salah satu factor yang berpengaruh terhadap partisipasi pasien dalam latihan fisik adalah adanya masukan dari healthcare provider (Johansen, 2017).

\section{KESIMPULAN}

1. Mayoritas responden berusia 46-55 tahun (46,7\%), mayoritas berjenis kelamin perempuan $(77,8 \%)$, paling banyak berpendidikan SMA $(46,7 \%)$, sebagian besar tidak bekerja $(64,4 \%)$

2. Terdapat pengaruh pemberian latihan fisik terhadap peningkatan kekuatan otot tangan pada pasien yang menjalani hemodialisis.

3. Terdapat pengaruh yang signifikan pemberian latihan fisik terhadap 
kekuatan otot tangan dan otot kaki pada pasien yang menjalani hemodialisis.

\section{DAFTAR PUSTAKA}

Alimul, A. (2009). Metode penelitian Keperawatan dan Teknik Analisa Data. Jakarta: Salemba Medika.

Anggreini, R., Jeavery, B., Franly, O. (2016). Faktor-faktor yang berhubungan dengan kepatuhan menjalani terapi hemodialisa pada penyakit ginjal kronik di ruangan dahlia dan melati RSUP Prof. Dr.

R. D Kanou Manado. e-journal Keperawatan (e-Kp) Volume 4 Nomor 2 agustus 2016.

Ariani, Sofia. (2016). Stop Gagal Ginjal dan Gangguan-gangguan Ginjal lainnya. Yogyakarta.

Aru, sudoyo. (2011). Ilmu penyakit dalam jilid IV edisi I. Pusat penerbitan departemen ilmu penyakit dalam FKUI, Jakarta.

Black, J.M.,\&Hawks, J.H. 2011. Medikal Surgical Nursing Clinical Management for Positive Outcome. $8^{\text {th }}$ ed. St.Louis: Elsevier

Dwi, R. (2014). Efektifitas latihan fisik selama hemodialisis terhadap peningkatan kekuatan otot pasien penyakit ginjal kronik di rumah sakit umum daerah kota semarang, Tesis,Universitas Indonesia Jakarta, Jakarta.

Fitriana, E. (2012). Hubunggan antara lama hemodialisa dan faktor komorbiditas dengan kemarian pasien gagal ginjal kronik di RSUD DR. Moewardi.Skripsi strata satu, Prodi kesehatan masyarakat fakultas ilmu kesehatan Universitas Muhammadiyah Surakarta.

Firmansyah, A.M. (2010). Usaha memperlambat perburukanpenyakit ginjal kronik ke penyakit ginjal stadium akhir. Cermin Dunia Kedokteran; ISSN: 0125-913 X/176/vol. 37 no. 3 april 2010.

Nursalam. 2011. Asuhan Keperawatan Pada Pasien Dengan Gangguan Sistem Perkemihan. Jakarta: Salemba Medika.

Notoadmojo. 2012. Pendidikan dan Perilaku Kesehatan, Jakarta: Rineka Cipta. 
Rybski M. 2011 Kinesiologi for occupational therapy. Slack incorporated

Saferi, Andra dkk.2013.Keperawatan Medikal Bedah I. Yogyakarta:Nuha Medika.

Seto, Darma. 2015. Penyakit Ginjal Deteksi Dini dan Pencegahan. Yogyakarta: ISBN: 978-602-702815-9
Suleman. A Riaz. K 2011. Exercise physiologi Fundation. Physiologi :emedicine sport medicine update 10 September 2008, di peroleh melalui hhtp;//www.kidney.org, tanggal 20 februari 2017

Widiastuti. 2011. Tes dan Pengukuran Olahraga. Jakarta: Bumi Putra Jaya. 